\title{
CREDIT AND ECONOMIC REGENERATION AFTER THE FINANCIAL CRISIS IN CESEE
}

\author{
Bekim Stafai ${ }^{1}$, Rilind Ademi²
}

\begin{abstract}
The global financial crisis terminated lending growth rates in CESEE countries, and seven years after financial global crisis, bank credit still continues with depression rate. Demand and supply for bank credit are contracted, as a results of various factors. The paper tries to find the level of credit contraction and factors that may have affected it, as well as policy action which are being taken to improve bank performance. Economic activity on the other hand, despite the depressed credit growth rates seem to show a trend of regeneration. This phenomenon of increasing economic activity without the support of the loan seems is happening in this postcrisis period in CESEE countries, although we must say that it remains undesirable phenomenon.
\end{abstract}

JEL classification number: G21, G01, DOI: http://dx.doi.org/10.12955/cbup.v4.756

UDC Classification: $336.7,338.1$

Keywords: bank credit, financial crisis, economic activity.

\section{Introduction}

In the spring of 2007, the crisis in the US subprime market breaks out very fast and consequently repercussions were felt throughout the world, especially in Europe. In one integrated financial world, where many assets were traded in the international market, the infectious effects were immediate and very much stressed out. The global financial crisis of 2008 erupted differently from previous crises. Compared with the other episodically crisis from before, when the low credit rates were part of the developing countries, this time, the crisis were more felt in the developed countries of the world, most of these countries still suffer from the effects remained in the global financial crisis, and emerging countries were generally resilient.

Respectively, even in Europe the crisis spread out through many channels, most of them closely related to the cross-border financing and banking relations.

In this context, the liquidity channel was in a critical condition, causing liquidity drainage, driven by the major global banks. There was a big drop of the capital move, compared to the pre-crisis levels. There was also decline in cross border flows, and that consequently resulted caused the banks to do a consolidation of the interior domestic banking system.

Also in CESEE the credit growth rates were interrupted with the escalation of the global financial crisis and as in developed countries, as well as in developing countries, the financial crisis caused repercussions consequences. The credit rise dropped to very low rate, and in some countries negative values were attained. The risk premises for credit giving were risen up, important economic indicators, FDI inflows, industrial production and exports deteriorated. The economic activity weakened very quickly, and many countries in the region experienced a large decline of the industrial production and the bank crediting began to be weakening after a long period of time.

However, the experience endured by the CEE and SEE countries wasn't same as the experience of the developing countries. Except that during 2008 - 2009 the crediting level significantly decreased, but still with some exceptions it also recorded some depressive lending rates and created one uncertain perspective towards a future growth.

The credit growth rates for the region dropped several times, with a growth rate of $31 \%$ average in the region during the years before the crisis, to an annual increasing rate of $3.38 \%$ after the crisis. On quarterly basis, the average before the crisis was $6.62 \%$ and with the emergence of the crisis reached up to $1 \%$. What is worth mentioning here is that, these kinds of rates remain the same still 7 years from the crises emergence. Thus, the study aims to reveal the loan rates after the crisis, comparing it to other regions. Then, by using different data we present a complex of indicators concerning the factors of influence, or the applied policies for an improvement. With CESEE countries in this studies we referred 15 states that: Albania, B and H, Bulgaria, Croatia, Hungary, Czech Republic, Macedonia,

\footnotetext{
${ }^{1}$ Bekim Stafai, Economic Faculty, European University of Tirana, Tirana, Albania, bstafai@ hotmail.com.

${ }^{2}$ Rilind Ademi, Economic Faculty, European University of Tirana, Tirana, Albania, rilind.ademi@ yahoo.com
} 
Moldova, Montenegro, Poland, Romania, Serbia, Slovenia, Slovakia, Ukraine. Some of the other countries in this region such as Turkey and Russia are excluded from the analysis due to the size and economic importance have as big countries, and also the Baltic states are excluded as a result of a different behavior of indicators that tend to analyzing. Also this paper didn't attempt to examine whether each country was affected by the financial crisis, or what is the rate of infection from the financial crisis. It was generally accepted by many authors that 4th quarter of 2008 was a beginning of the financial crisis in the region.

When in early September, officials of the IMF appeared before the media to report on the October 2008 World Economic Outlook, the signs of crisis were beginning to appear at the CESEE countries and enthusiastic nuances faded that this region remained untouched by the wave of global financial crisis, so followed correcting projections on economic growth. The global crisis expanded rapidly in CESEE countries after mid-September 2008 through financial and trade routes, when the Lehman Brothers announced bankruptcy. Was a matter of weeks, when financial markets were frozen and international trade collapsed, hitting the region even worse than the most pessimistic expectations.

Crucial in this study is the behavior of the economic activity and the credit. As shown by the indicators and by a simple correlation between these two variables, the economic activity has one increasing rate and one tendency for return to the pre-crisis rates, while the crediting activity has a depressive move.

\section{Credit activity and the post global financial crisis period}

The global financial crisis of 2008 came in different way from previous crises. Different from other occurrences with lower credit rates from the developing countries, this time on the focus of the crisis were the developed countries of the world, and most of these countries still suffer from the consequences of the global financial crisis, and emerging countries were generally flexible.

But the experience endured by CESEE countries is different from the experience of the developing countries. Except that during 2008 - 2009 the level of crediting significantly decreased, moreover it recorded, with some exceptions, depressive crediting rates and created an uncertain perspective towards future growth.

In figure 1 is shown the credit growth over the years, before and after the occurrence of the crisis. It seems that after major failures of credit rates during the crisis between 2008-2009, the credit remained quite weak bringing even shrinking credit rates.

A saying is relevant for occasion, "when developed countries have cold, the developing countries get pneumonia". This probably does not apply to all developing regions and should not be generalized, but from the chart we can see that it is relevant for CESEE country. After the credit boom, the crisis interrupts the high rates of credit growth (vertical red line) and from it, on average, loan rates from that point are close to zero (see the green line of the graph). But Turkey and Russia are an exception, since after a great decline of the credit increase in 2009, they started again with high rates of credit growth in both countries.

From a different review and with the same outcome is represented the table below, where the credit growth rates for different countries is shown. Table 1 classifies the countries in 4 groups according to the credit growth for the period of Q2 2013 - Q2 2015. The first column indicates that credit in most developed countries is shrinking or at a very low levels (-10 to $0 \%$ increase quarterly), and for some countries there is a moderate increase. In contrast to this, the second column indicates that some nonEuropean countries show clear signs of improving credit rates.

In the case of CEESE as a whole, very easily, with a few exceptions, can be noted down that the loans are at shrinking level, or moderate level, expressing once again a concern about possibility that these rhythms post crisis to be "normal" credit growth.

Deleverage process, measured by loan/deposit ratio is still running ${ }^{3}$. However, in 2015 only threequarters of the banking group expect a reduction of the credit / deposit ratio, and from the chart we can

\footnotetext{
3 The loan-to-deposit ratio (LTD) is a commonly used statistic for assessing a bank's liquidity by dividing the banks total loans by its total deposits. This number, also known as the LTD ratio, is expressed as a percentage. If the ratio is too high, it means that banks might not have enough liquidity to cover any unforseen fund requirements; if the ratio is too low, banks may not be earning as much as they could be.
} 
see that the years 2013 and 2014 were even worse in terms of the expectations of banks regarding this ratio. Most banks reported that they will continue with a stable level of credit / deposit ratio, while a few stated that they will even increase (EIB, 2015). From this we can see that banks are still not ready to return the rhythms of credit allocations as before the crisis, although it is worth mentioning that expectations compared to 2014 and 2013 were relatively improved (see figure 2b).

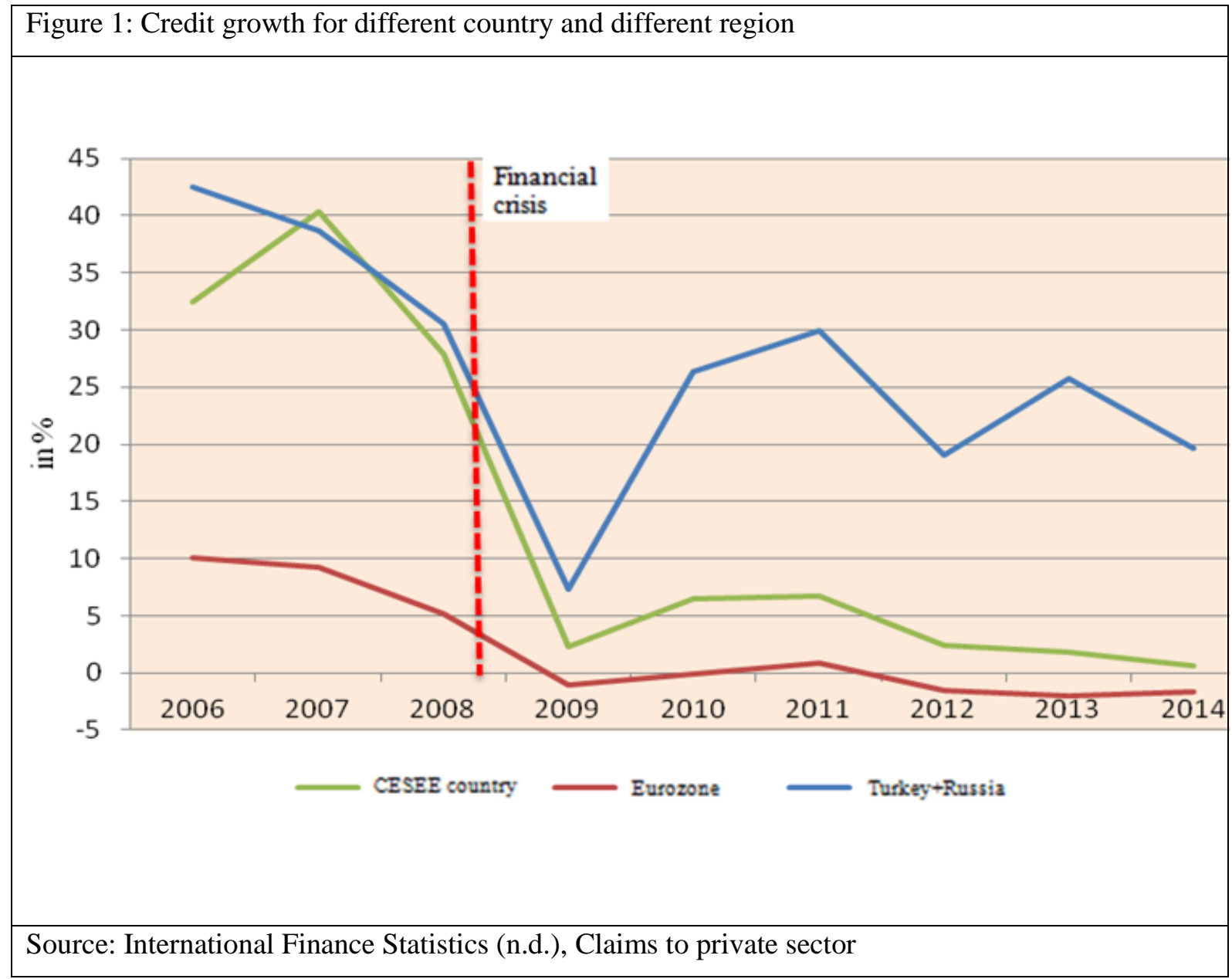

The financial crisis stroke precisely on the capital flows transferred from abroad in cross-border crediting ways, in one way the sufferings of most large international banks appear seemed to have limited the supply of cross-border lending. This finding is consistent with the general understanding that this period of financial crisis originally came out of developing markets. The cross-border bank crediting was one of the channels through which the crisis came in the developing markets. Consequently, higher levels of crediting before the crisis were correlated with the capital flows from abroad, through the bank subsidiaries of multinational banks. Thus, it is obvious that after a period of the crisis, such flows cannot be put to the pre-crisis levels.

Cross-border claims continued still with a discriminatory strategy for the CESEE countries. Although there are six years since the occurrence of the crisis, yet powerful banking groups are reluctant to expand banking operations in these countries. In 2013-2014 (EIB, 2015), 60\% of banking groups planned to reduce the level of bank operations in these countries, or to keep the same level and only $40 \%$ expected an increase of operations (see Figure 3).

According to the survey in the first half of 2015, there were signs of improvement although in a discriminatory level, where $55 \%$ of the groups expected to expand their operations (or to expand selectively). According to the survey, all of this came as a result of lower profitability, weakening the potential of the banking market and demand lowering. 
Figure 3: Long-term strategy of the banking groups in CESEE (for 12 months)

\begin{tabular}{|c|c|c|c|c|c|c|}
\hline & $\begin{array}{l}\text { Reduce } \\
\text { operations }\end{array}$ & $\begin{array}{l}\text { Selectively } \\
\text { reduce } \\
\text { operations }\end{array}$ & $\begin{array}{l}\text { Maintain the } \\
\text { same level of } \\
\text { operations via } \\
\text { subsidaries }\end{array}$ & $\begin{array}{l}\text { Selectively } \\
\text { expand } \\
\text { operations in } \\
\text { certain country }\end{array}$ & $\begin{array}{l}\text { Expand } \\
\text { operations }\end{array}$ & \\
\hline 50 & & & & $47 \%$ & & \\
\hline 40 & & & & & & \\
\hline 35 & & & $33 \%$ & & & $\mathrm{H}-\mathrm{I}-2015$ \\
\hline 30 & & $27 \%$ & & $30 \%$ & & [2013-2014 \\
\hline 20 & & $24 \%$ & $20 \%$ & & & \\
\hline 15 & & & & & $10 \%$ & \\
\hline 10 & & & & & $\%$ & \\
\hline 5 & $0 \%$ & & & & & \\
\hline
\end{tabular}

Figure 4: Total and supply, past and expected development; net percentages; positive figures refer to increasing (easing) demand (supply).

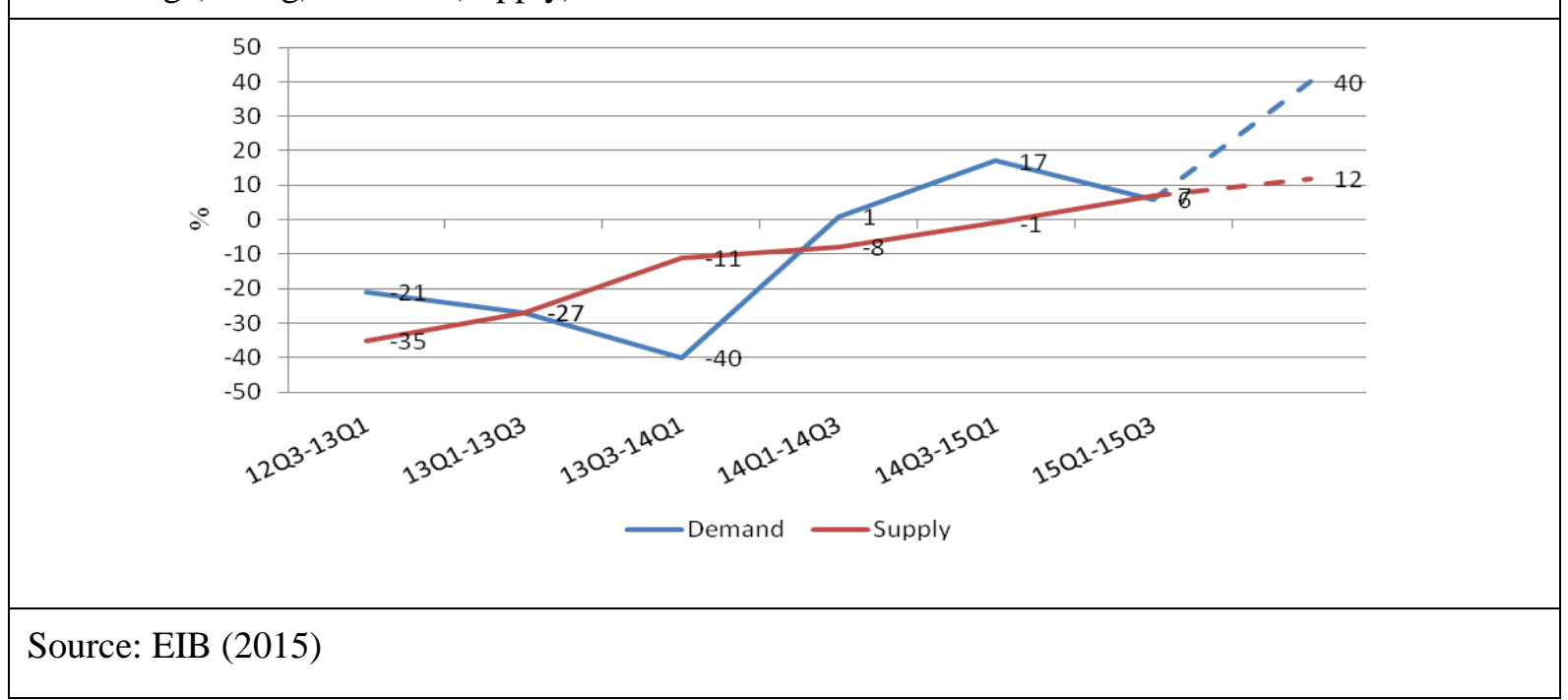

Figure 4 shows the evolution of the supply and demand factors that affect in the limiting of the credit increase. If indicators are negative, that means things are getting worse in terms of the credit growth and vice versa. According to the graph, the climate and conditions on the side of the demand were deteriorating and then got stabilized, especially after 2014, being shown as positive. On the side of the supply, things were worse.

The next question is what do the banks expect? Will the conditions be getting improved or worsening? During the next six months (the trend with discontinued lines) bankers will expect an improved situation (especially on the demand side).

Whereas, in order to reveal exactly the factors that shrink the crediting offer, and if it is in an uncertain state after the crisis, the following figure can show it better. At this one where indicators are positive it means that crediting conditions are improving and vice versa for the negative values.

The non-performing loans and the regulatory environment at the local level as well as at international level, occur to be the main factors that mainly limit the crediting offer. This graph is also consist of indicators of 2013 (the green triangles in figure 5), where it shown that almost all local or international factors have one negative impact on the credit supply offer. However, recent research indicates that only the non-performing loans and the regulatory environment remain elements that restrict the credit supply. 
Figure 5: Factors contributing to supply conditions (credit standards) - (net percentage; positive figures refer to a positive contribution to supply)

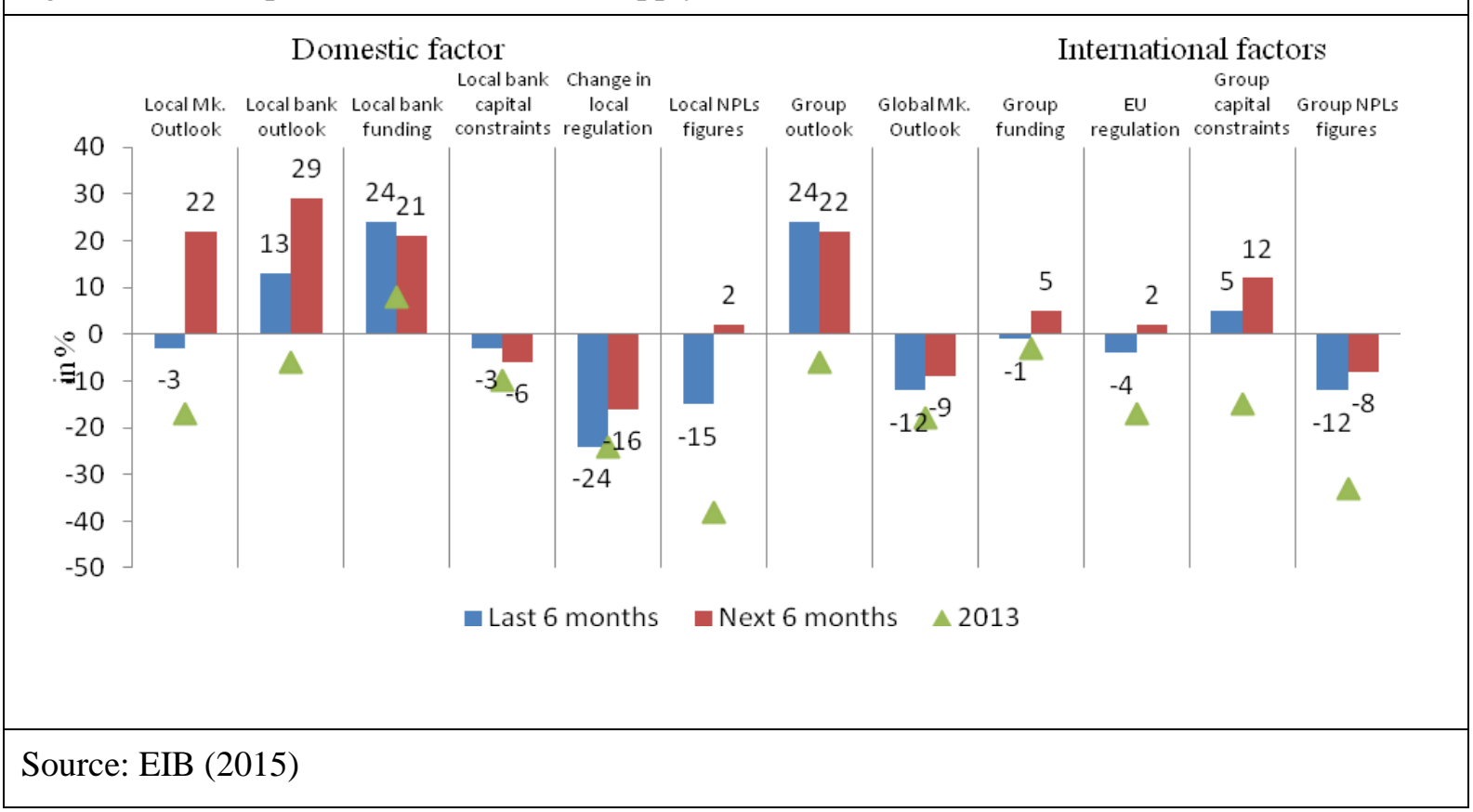

\section{Policy activity}

According to the table presented above, the credit growth in the countries of SEE and CEE, but also in the euro zone was shrinking or moderated, which means that the credit increases are either negative, or at the most can have an increase up to $3 \%$ on quarterly basis. Under these circumstances it was very necessary by the policy makers to restore the economic activity through an increased support for crediting. For this we rely on a study of IMF done in 2013 for 42 countries, among which the countries of CESEE published in Global Financial Stability Report (GFSR -The General Report for Stability and Finance).

Figure 6 : The relative number of the policies for credit supply and demand for different countries

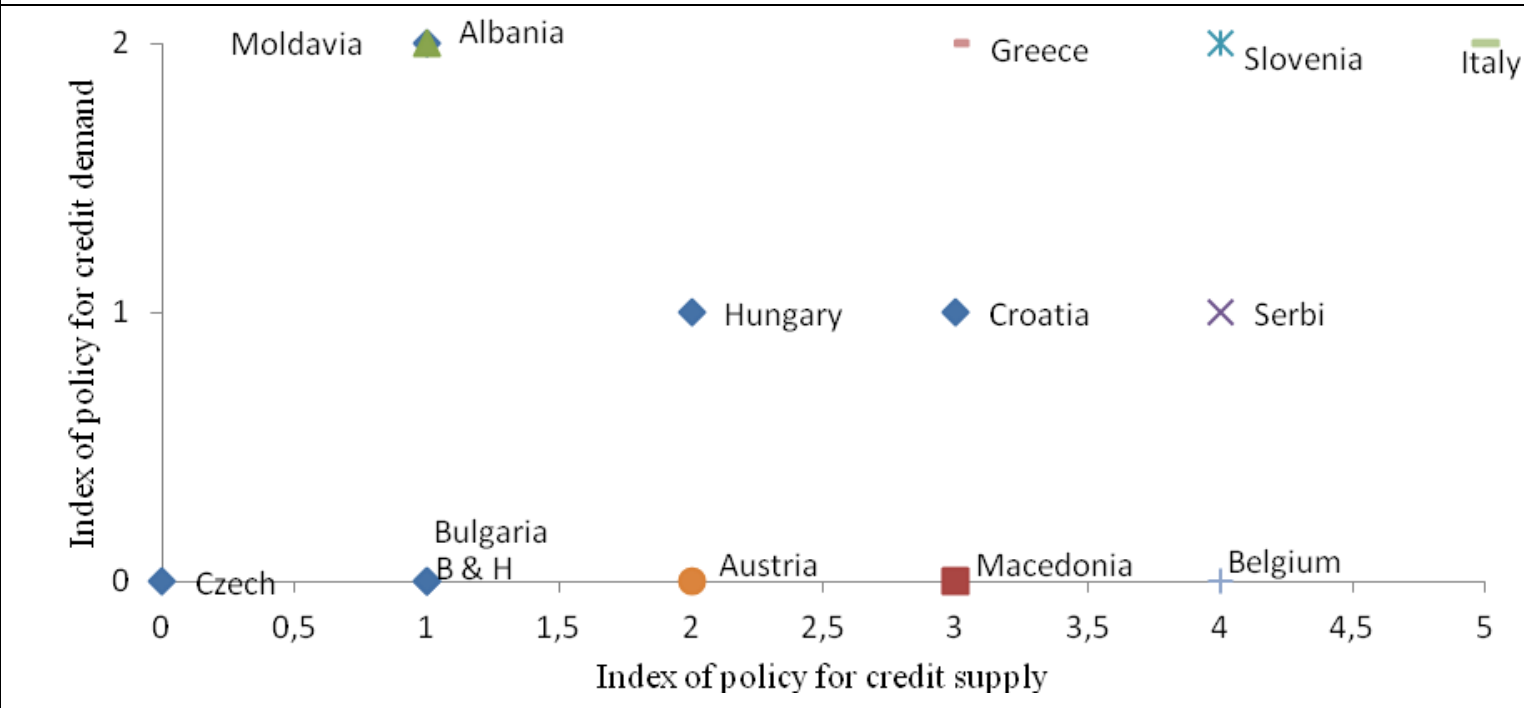

Source: International Monetary Fund (2013) 
CBU INTERNATIONAL CONFERENCE ON INNOVATIONS IN SCIENCE AND EDUCATION

Table 2: Crediting Policies applied from 2007

\begin{tabular}{|c|c|c|c|c|c|c|c|}
\hline & \multicolumn{5}{|c|}{ Expansion of credit supply } & \multicolumn{2}{|c|}{$\begin{array}{l}\text { Supporting policy for credit } \\
\text { demand }\end{array}$} \\
\hline & $\begin{array}{l}\text { Monetary } \\
\text { Policy }^{1}\end{array}$ & $\begin{array}{l}\text { Fiscal } \\
\text { Crediting } \\
\text { Programs }^{2} \\
\end{array}$ & $\begin{array}{l}\text { The support of } \\
\text { Finance } \\
\text { Regulations }{ }^{3}\end{array}$ & $\begin{array}{l}\text { Masses of } \\
\text { the Market } \\
\text { Capital }^{4}\end{array}$ & $\begin{array}{l}\text { Banking } \\
\text { Restructure }^{5}\end{array}$ & $\begin{array}{l}\text { Corporate debt } \\
\text { restructuring }\end{array}$ & $\begin{array}{l}\text { Households } \\
\text { debt } \\
\text { restructuring }\end{array}$ \\
\hline \multicolumn{8}{|l|}{ Eurozone } \\
\hline Austria & $\mathrm{Y}$ & & & & $\mathrm{Y}$ & & \\
\hline Belgium & $\mathrm{Y}$ & $\mathrm{Y}$ & & $\mathrm{Y}$ & $\mathrm{Y}$ & & \\
\hline Estonia & $\mathrm{Y}$ & & & & & $\mathrm{Y}$ & $\mathrm{Y}$ \\
\hline Finland & $\mathrm{Y}$ & & & & & & \\
\hline France & $\mathrm{Y}$ & & & $\bar{Y}$ & $\bar{Y}$ & & \\
\hline Germany & $\mathrm{Y}$ & Y & & & $\mathrm{Y}$ & & \\
\hline Greece & Y & Y & & & Y & $\mathrm{Y}$ & $\mathrm{Y}$ \\
\hline Ireland & $\mathrm{Y}$ & Y & & & $\mathrm{Y}$ & Y & $\mathrm{Y}$ \\
\hline Italy & $\mathrm{Y}$ & Y & Y & $\mathrm{Y}$ & $\mathrm{Y}$ & $\mathrm{Y}$ & $\mathrm{Y}$ \\
\hline Netherland & Y & Y & & $\mathrm{Y}$ & Y & & \\
\hline Portugal & $\mathrm{Y}$ & $\mathrm{Y}$ & & & $\mathrm{Y}$ & $\mathrm{Y}$ & $\mathrm{Y}$ \\
\hline Slovakia & $\mathrm{Y}$ & & & & & & \\
\hline Slovenia & $\mathrm{Y}$ & $\mathrm{Y}$ & $\mathrm{Y}$ & & $\mathrm{Y}$ & $\mathrm{Y}$ & $\mathrm{Y}$ \\
\hline Spain & $\mathrm{Y}$ & $\mathrm{Y}$ & & Y & $\mathrm{Y}$ & $\mathrm{Y}$ & $\mathrm{Y}$ \\
\hline \multicolumn{8}{|l|}{ CESEE } \\
\hline Albania & & & $\mathrm{Y}$ & & & $\mathrm{Y}$ & $\mathrm{Y}$ \\
\hline $\mathrm{B}$ and $\mathrm{H}$ & & & & & $\bar{Y}$ & & \\
\hline Bulgaria & & & $\mathrm{Y}$ & & & & \\
\hline Croatia & $\bar{Y}$ & $\bar{Y}$ & $\bar{Y}$ & & & $\bar{Y}$ & \\
\hline \multicolumn{8}{|l|}{ Czech } \\
\hline Hungary & $\mathrm{Y}$ & $\mathrm{Y}$ & & & & & $\bar{Y}$ \\
\hline Letonia & & & & & $\mathrm{Y}$ & $\mathrm{y}$ & $\mathrm{Y}$ \\
\hline Lithuania & & $\mathrm{Y}$ & & & & & $\mathrm{Y}$ \\
\hline Macedonia & $\mathrm{Y}$ & $\mathrm{Y}$ & $\mathrm{Y}$ & & & & \\
\hline Moldovia & $\mathrm{Y}$ & & & & & $\mathrm{Y}$ & $\mathrm{Y}$ \\
\hline Montenegro & & $\mathrm{Y}$ & & & & & \\
\hline Poland & & $\mathrm{Y}$ & & & & & \\
\hline Romania & & $\mathrm{Y}$ & $\mathrm{Y}$ & & & $\mathrm{Y}$ & \\
\hline Russia & $\mathrm{Y}$ & $\mathrm{Y}$ & $\mathrm{Y}$ & & $\mathrm{Y}$ & & \\
\hline Serbia & $\bar{Y}$ & $\bar{Y}$ & $\bar{Y}$ & & $\bar{Y}$ & $\mathrm{Y}$ & \\
\hline \multicolumn{8}{|l|}{ Turkey } \\
\hline Ukraine & $\mathrm{Y}$ & $\mathrm{Y}$ & & & $\mathrm{Y}$ & $\mathrm{Y}$ & \\
\hline \multicolumn{8}{|c|}{$\begin{array}{l}\text { Note: This table lists the various policy measures undertaken since } 2007 \text { excluding the scope, duration or effectiveness of these policies. } \\
\text { Detailed tables with data on various policy measures is available online: http://www.imf.org/External/Pubs/FT/GFSR/2013/02/pdf/appendix2_1.pdf } \\
\text { 1) Monetary policy - central banks used monetary instruments in order to stimulate supply and credit demand. } \\
\text { 2) Fiscal programs - many national budgets have tried to promote corporate loan or mortgage through credit expansion directly or through } \\
\text { subsidies. } \\
\text { 3) Attentive Regulators have established measures designed to facilitate the restrictions on bank balance sheets due to the creation of new bank } \\
\text { loans. } \\
\text { 4) Measures of market capital - For promoting diversification with financing options of the firms, many governments have made efforts to reduce } \\
\text { the barriers for the issuance of bonds to SMEs and to promote loans security to SMEs and households debts. } \\
\text { 5) The bank restructuring - Many governments have recapitalized the banks, have implemented programs to purchase troubled assets and provided } \\
\text { bank guarantees for existing assets. } \\
\text { 6) Corporate debt restructuring - To facilitate the corporate debt, which had a depressive credit demand, many governments had undertaken } \\
\text { measures to restructure the corporate debts through the state property banks and through the management companies with assets that took over the } \\
\text { troubled assets of the banks. } \\
\text { 7) Household debt restructuring - One similar strategy with debt restructuring in the corporate, was of some governments which tried to facilitate } \\
\text { the family debt restructuring by implementing restructure programs of family debts. }\end{array}$} \\
\hline
\end{tabular}


This study aims at identify all the activity being taken in various countries for the recovery of the banking activity. On the supply side, there are 50 separate policies put in 5 categories: monetary policy, fiscal crediting programs, supportive regulations of the financial sector, measures in the capital market and banks restructure. On the demand side, there are measures related to the corporate and households' debt restructuring. Most of the countries have used a combined policy or taken measures to support both demand as well as credit supply. From the factors affecting the shrinking of the credit mass as mentioned above, these policies are intended to eliminate the restrictions mentioned due to its improving credit measures. But this does not mean that these measures are recommendable. For its clarification, some can be effective or under certain circumstances may be accompanied by higher costs than benefit. The study aims to make a full scientific research on the measures adapted from 2007. In Table 2, the cells with the letter "Y" describe the measures that have been implemented. It does not describe the specific measure being taken or how profound it was, or how effective was it.

One thing that can be noticed in the table is that the amount of bank restructuring is less used in the SEE countries and CEE compared to developed European countries. This means that the banks in developing countries were less infected with active "toxics", and once again it shows that the origin of the crisis, this time, came from the developed industrial countries.

From table 2 and figure 6 is obvious that the policy of expansion of credit supply were more used especially monetary policy measures, measures of fiscal policy and the banking restructuring. As it appears from the table the capital market measures which means relief for the issuance of bonds and SME loans and the securitizations of the credits was not practiced in none of the countries of SEE and CEE.

On the demand part, the picture has more mixed nature. For some European countries that dealt with a more robust crisis (as Greece, Ireland, Spain, Portugal) there was an implementation of the policies for corporate debt restructure as well as for households.

It is worth mentioning that most countries were based on a variety of policies, supported by the supply as well as by the demand for credit, recognizing the same time that these are often complementary (Jazbec, Towe, Piñon, \& Banerjee, 2015).

From the results and research it turned to be that the developing CESEE countries have implemented a number of less measures for credit support, perhaps from the tiny monetary and fiscal spaces for a maneuver (see Table 2 and Figure 6).

\section{The Credit and Economic recovery after the financial crisis}

The importance of bank crediting for the improvement of economic activity is well developed and generally its theories are well known. Bank credit finance investments, working capital, technology and consumer components. A disruption of credit, driven by the economy can cause contractions in the economic activity. From a large number of studies and a long-term perspective, credit mass were an important factor for the economic development. But the economic activity recovery with no credit increase shouldn't be interpreted as a surprise. The slow recovery of credit is even a common characteristic of the process of recovery from a financial crisis or an economic stagnation of a developing country. So the improvement of the output without improving the credit is not a rare phenomenon. One of the first researcher who documented this phenomenon (Calvo, Izquierdo, \& Talvi, 2006) described it as a miracle where "Phoenix rises from its own ashes," with no help from the credit. It was revealed that after an economic and financial crisis, the output tends to return soon to its pre-crisis level, but practically with no revival of the bank crediting and the investments remained at low levels (which can be seen from the figure 7).

These theories and assertions seem to be true for the CESEE countries in the period after the global financial crisis, where the GDP growth rates tended to return to the pre-crisis levels but not the credit. The data in the following charts for the GDP rates and credit measures were taken by the IMF (International Financial Statistics) and were processed by the Hodrick Prescott filter $(\Lambda=1600)$ on quarterly basis, in order to benefit the long-term trend line. 
Graph 7: Relations credit-economic activity for the CESEE countries

a) Actual crediting rate and the credit trend for the CESEE countries, on quarterly basis

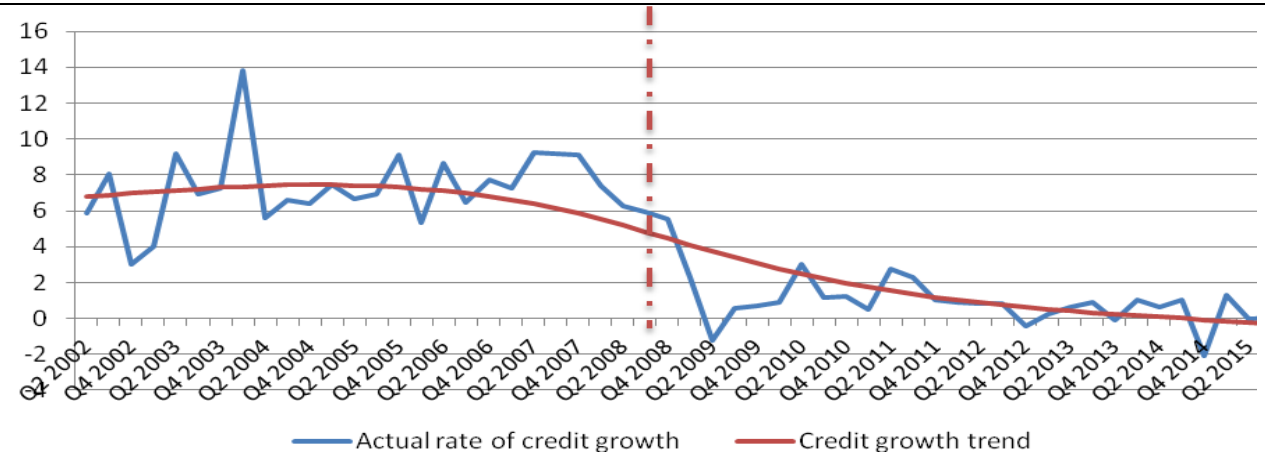

b)The real increase of the GDP and the increase rate of the GDP for CESEE, on quarterly basis

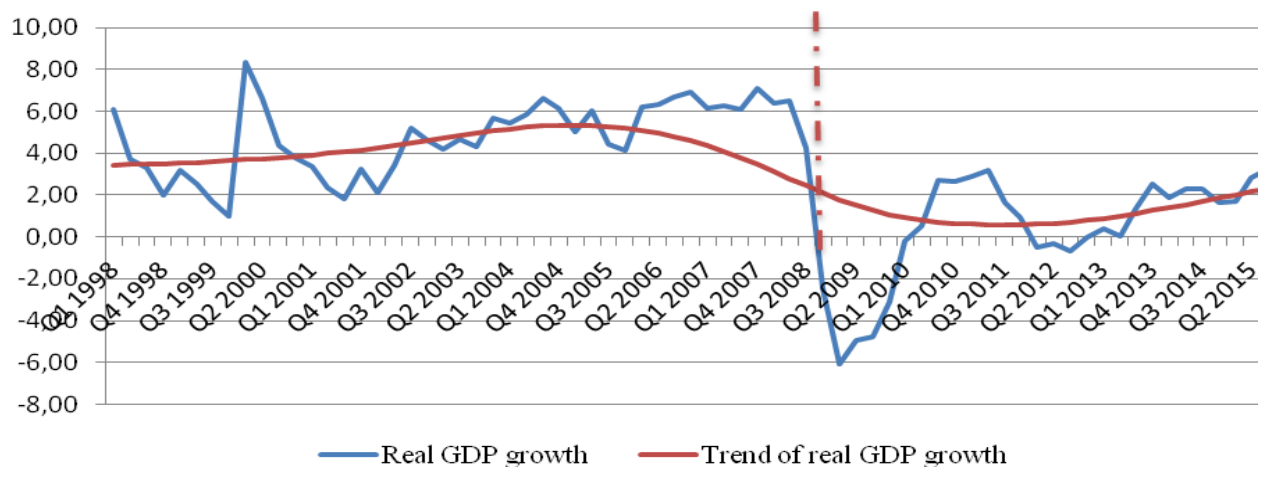

c) The economic increase and the bank crediting increase in CESEE

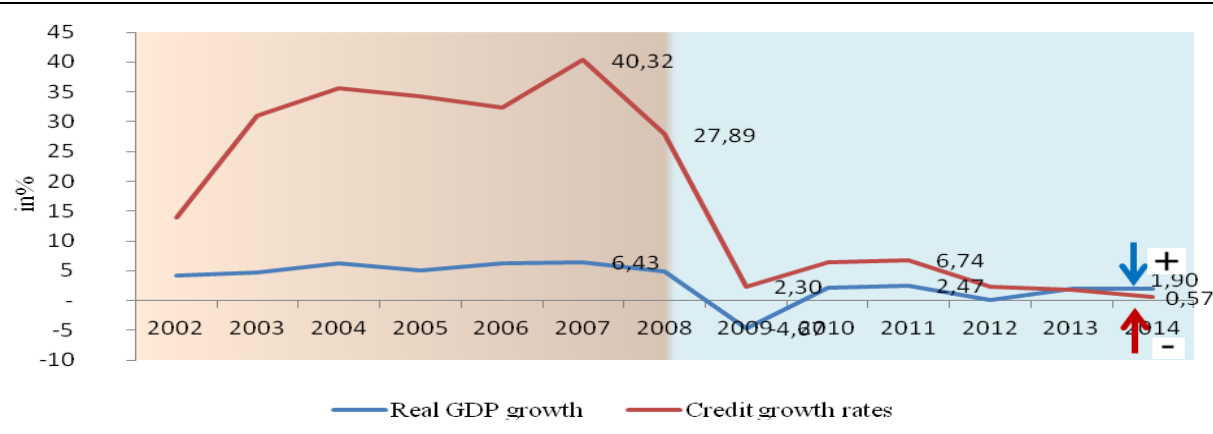

Source: International Finance Statistics (IFS) (n.d) and author calculations

The indication for the credit and the GDP are an average of the countries from the region. From the figures we can see that the GDP with the dropped down quickly (red dotted line), but the trend began to improve and from 2014 recorded an increasing rates of $2 \%$. Whereas, on the other hand, the credit rate rise were cut out during the crisis (red dotted line) and trend of loan rates had no improvements, approaching to zero level, and it became even negative. As it is shown in the figures, countries were concerned with an attempt to support the economic recovery with no crediting. But, as pointed out earlier, this phenomenon, isn't rare, the economic activity are usually revitalized without the support of credit, especially in developing countries.

To explain this paradox of an economic growth without an increase in credit (Biggs, Mayer, \& Pick, 2009) used a model of one closed economy to show whether loan rates are important for the increase of the output after a financial crisis. One of the reasons of this growth, is that the loan rates stops the decreasing rates, even when they get negative. 
Another reason is that the link between the economic activity and the credit is different in different periods. In 'normal' periods, the credit measures and credit rates, as well, are important for the credit growth, while in the period of financial instability, the credit growth loses its importance as one influencing in the economic growth.

Another reason is that the level of financial intermediation is over shadowed by the events that have hindered the credit supply (credit booms or banking crises). This explanation is based on the findings that industries that are more dependent on external financing seems to have grown less during the crediting recovery (Abiad \& Dell'Ariccia, 2011)

Table 3: Average annual growth of the real GDP (\%) during the first three years of recovery

\begin{tabular}{|l|l|l|l|l|}
\hline & Observations & First three years & \multirow{2}{*}{} \\
\cline { 2 - 4 } & "Normal" Recovery & 157 & 8,6 \\
\cline { 2 - 4 } & Recovery with low credit & 54 & 4,8 \\
\hline
\end{tabular}

Source: Bijsterbosch \& Dahlhaus (2011)

One conclusion from these studies can be found, despite the findings from the output, as it is returning the increase rate with no credit return, but still regeneration with low rates is less "desirable". From a study of 86 countries with low or medium income (Bijsterbosch \&, Dahlhaus, 2011), for a period from 1970 to 2009 is obvious that for the first three years, the economic recovery is higher, on average $8,6 \%$, compared to the periods where the credit is not present, where the average increases to $4.8 \%$. Also, from this is obvious that the economic recovery with no credit support is not something impossible, and $1 / 3$ of the cases included in the study are with no credit support.

These indicators reflect that the economic recoveries with no credit support are slower and with lower rates.

\section{Conclusion}

The emerge of the financial crisis, significantly disrupted the credit rates in the CESEE countries. The declining and depressive rates, are still present, 7-8 years after the occurrence of the crisis in this region. These countries, with a large foreign capital in the banking sector, were significantly affected by an interruption of crediting from large banking groups run through their subsidiaries in the region.

Even during these years, more than half of the banking group, plan and anticipate the reduction of bank operations in the region of SEE and CEE countries. The problematic loans and the regulatory environment seem to be one of the factors that negatively affect the credit supply. These countries have created an economic environment with the economic growth recovery trends, tends to return to its pre-crisis climate, without crediting support. Apparently this is treated as a normal phenomenon after a period of economic and financial crisis that severely hit banking liquidity. Regardless of this, from the statistical evaluations it is concluded that the economic recovery without credit re-activation is less desirable.

\section{References}

Abiad, G., \& Dell'Ariccia, B. L., (2011 March). Creditless Recoveries, IMF Working Paper, WP/11/58.

Biggs, M., Mayer, T., \& Pick, A. (2009). Credit and economic recovery, Working Paper 218, DNB.

Bijsterbosch,M., Dahlhaus,T, (2011 June). Determinants of credit-less recoveries, Working Paper Series, ECB, No.1358.

Calvo, G. A., Izquierdo, A., \& Talvi, E. (2006). Phoenix miracles in emerging markets:Recovering without credit from systemic banking crises, Working Paper 570, Inter-American Development Bank.

European Investment Bank (EIB) (2015). CESEE Bank Lending Survey - H1 2015.

International Finance Statistics (IFS) (n.d.). International Monetary Fund (IMF), retrieved from http://data.imf.org/?sk=5DABAFF2-C5AD-4D27-A175-1253419C02D1

International Monetary Fund (2013). Global financial stability report 2013, World Economic and Financial Surveys, Washington D.C.

Jazbec, B., Towe, C., Piñon, M., \& Banerjee, B., (2015). Reinvigorating Credit Growth in Central, Eastern, and Southern European Economies, Chapter III "What is driving kredit developments, Can something be done?", pg.29, IMF, Bank of Slovenija. 